\title{
Does Knowledge Management Deliver the Goods in SMEs?
}

\author{
Ingi Runar Edvardsson ${ }^{1} \&$ Susanne Durst ${ }^{2}$ \\ ${ }^{1}$ School of Business, University of Iceland, Reykjavik, Iceland \\ ${ }^{2}$ Institute for Entrepreneurship, University of Liechtenstein,Vaduz, Principality of Liechtenstein \\ Correspondence: Ingi Runar Edvardsson, University of Iceland, Gimli, 101 Reykjavik, Iceland. Tel. 354-8647790. \\ E-mail: ire@hi.is
}

Received: May 17, 2013

Accepted: June 3, 2013

Online Published: June 4, 2013

doi:10.5430/bmr.v2n2p52

URL: http://dx.doi.org/10.5430/bmr.v2n2p52

\begin{abstract}
The purpose of this paper is to review research on knowledge management's benefits within small and medium-sized firms. The paper attempts to answer the following research questions: 1) Which studies have been conducted that focus on the benefits of KM within SMEs? 2) What were the main findings of the studies? 3) In what manner does KM improve innovation, quality, productivity, and competitive standing? 4) Where were these studies conducted? and 5) Which methods were used. We propose an approach comprising a literature review in order to understand knowledge benefits for SMEs. The findings show that the benefits of knowledge management in small and medium-sized firms represent a poorly understood area of research. The reviewed studies highlight the benefits of knowledge management in the areas of employee development, innovation, customer satisfaction and organisational success. Further research is needed in this area.
\end{abstract}

Keywords: Knowledge management, SMEs, Benefits, Outcome, Literature review

\section{Introduction}

The field of knowledge management (KM) has been growing extensively in recent years. Although there is an ever growing research on the subject, there is still no consensus on the definition of KM. In this paper we share the definition of Daft (2007, p. 452-453) where he states that the concept "refers to the efforts to systematically find, organize, and make available a company's intellectual capital and to foster a culture of continuous learning and knowledge sharing so that organizational activities build on what is already known". The extant literature provides a large volume of contributions discussing the relevance of KM in general (e.g. Davenport and Pursak, 1998; Nonaka and Takeuchi, 1995; O'Dell et al., 2003; O'Dell and Hubert, 2011); suitable KM processes and techniques (e.g. Davenport and Pursak, 1998; Kluge et al., 2003; Wiig, 1997, Jashapara, 2011; O'Dell and Hubert, 2011); the role of ICT (e.g. Tsui, 2003; Markus, 2006) and human resource management (e.g. Andreeva and Kianto, 2012; Edvardsson, 2008; Oltra, 2005; Liao, 2011). However, very limited empirical work has been undertaken in order to reveal the actual effect of KM in organizations, be they private or public. For instance, Choy et al. (2006) highlighted that as yet KM research has failed to provide a set of widely accepted measurement criteria for KM efforts. Durst and Edvardsson (2012) showed in their literature review that amongst other KM areas, particularly the issues of knowledge utilisation, or knowledge outcome, respectively, represent a neglected field of study, at least in the context of small and medium-sized enterprises (SME). The authors identified only two peer reviewed papers on the subject. Both articles confirmed the role of knowledge as a driver of innovation in enhancing customer satisfaction, as well as escalating profits and productivity. Similarly, Edvardsson and Oskarsson (2011) pointed out that there is lack of understanding of how firms create knowledge and of how this is translated into competitive advantage and enhanced customer relations. The validation of a causal relationship between KM programmes, on the one hand, and innovation, customer relationships and competitive advantage, on the other, is yet to emerge in the literature. This situation can be regarded as unsatisfactory and a failure of organizations to understand the impact of their KM initiatives may lead to discouraged engagement or, even worse, to their termination. Particularly in SMEs with their short stock of resources there is a need for improved understanding as this would help them to better control and allocate their resources regarding different business operations. Given the profound role of SMEs in most economies of the world, we see a clear justification for more intense research in this area.

Bearing this in mind, the purpose of our paper is to review former research on KM benefits within SMEs. The following research questions were formulated according to this aim: 1) Which studies have been conducted that 
focus on the benefits of KM within SMEs? 2) What were the main findings of the studies? 3) In what manner does KM improve innovation, quality, productivity, and competitive standing? 4) Where were these studies conducted? and 5) Which methods were used?

The paper is structured as follows: The following section of the paper deals with earlier research on the benefits of KM. Next, the research method is presented. The outcomes of the literature review are described in the findings section, and the paper terminates by a discussion and a conclusions section.

\subsection{KM and organizational performance}

By and large, previous observations stress a positive relationship between KM and organizational performance. Among the first surveys on the benefits of KM was the study published by KPMG Consulting (2000). The survey was based on responses from 423 large European and US companies. Fourteen expected and realized benefits were identified, ranging from decision making, marketing, cost reduction, innovation, to HRM and operational aspects. The most significant benefits realized by organizations that had KM programmes in place included improved decision making $(71 \%)$, faster responses to key business issues $(68 \%)$ and better customer handling (64\%). Surveys conducted among Icelandic firms came to rather similar conclusions (Edvardsson, 2006, 2009). An international web-survey among 122 firms also demonstrated that KM practices enhanced the general performance of organisations (Lim and Ahmed, 2000). Similar results were found in a survey conducted among German companies in 2002 (Edler, 2003), even though it has to be noted that the ranking of issues and the actual benefits vary between countries involved. Research among 40 organizations in Europe, the US and Japan suggested that the more successful KM companies outperform less successful companies with regard to increases in return on sales, rising sales, innovation rate, average development time, and reduction in throughput time (Kluge et al., 2001). The American Productivity and Quality Center (APQC) concludes that those organisations that most rigorously measure $\mathrm{KM}$ can show as much as a 200 percent return on investment (O'Dell and Hubert, 2011). In a recent paper, Andreeva and Kianto (2012) stressed the dearth of empirical studies showing the actual connection between knowledge management and organizational performance. The authors rightly observe that without a clear connection, any investments of organizations in KM activities can be regarded as useless, binding resources that might be better used in other business areas. To address this situation, they examined how KM practices impact firms' competitiveness and financial performance. By means of a survey approach, data was collected in Finland, Russia and China. The findings indicate a strong correlation between HRM and ICT practices for managing knowledge and their significant influence on both financial performance and corporate competitiveness. The findings further suggest that ICT practices can improve financial performance only when they are coupled with HRM practices.

Choy et al. (2006) identified 38 items for measuring KM outcomes from a literature review. The authors grouped these items into the following five dimensions: Systematic knowledge activities; employee development; customer satisfaction; good external relationships and organisational success.

Chong and Chong (2009), in their empirical study among managers in the Malaysian telecommunications industry, examined the association between five KM preliminary success factors (i.e. business strategy, organizational structure, KM team, knowledge map and knowledge audit), four KM elements of strategy (i.e. culture, leadership, measurement and technology) and KM process effectiveness. The study showed a close interaction between KM preliminary success factors and appropriate KM elements of strategy in reaching improved efficiency, better productivity and increased revenue.

The studies presented above indicate that a systematic knowledge management approach can have a positive effect on the performance of organizations. As the studies discussed so far address large organizations only, we turn to KM activities in smaller firms in the next section.

\section{$1.2 \mathrm{KM}$ in SMEs}

Often smaller companies have to deal with specific challenges in the area of KM which strongly differ from those faced by large businesses. As indicated by the literature, however, it is quite common, for SMEs, to adopt techniques which have been tried and tested in larger corporations. As a result, smaller firms risk losing their specific identity and efficiency which has been amply demonstrated in earlier research. Most SMEs lack explicit overall KM strategies, and consequently tend to treat $\mathrm{KM}$ on an operational level - focusing on systems and instruments (Beijerse, 2000; Hutchinson and Quintas, 2008). Compared to larger firms, SMEs tend to be more oriented towards the management of tacit knowledge, and their communication paths in SMEs often involve other companies, rather than remaining within the organisation. Thus, the SME sector appears to be less developed with regard to knowledge construction, towards which it displays a more mechanistic approach and is less involved in social interaction; the 
sector is also less successful in sharing tacit knowledge by means of formal and systematic discussion than is the case with larger companies (Beijerse, 2000; Matlay, 2000; McAdam and Reid, 2001; Corso et al., 2003; Bozbura, 2007; Hutchinson and Quintas, 2008). Furthermore, most SMEs manifest an informal short-term approach towards organisational learning, and managers in smaller firms may even obstruct the outflow of knowledge from the company, thus creating obstacles to knowledge sharing (Bozbura, 2007) which seriously impair the potential advantages of KM. The slow staff turnover, however, which tends to be a characteristic of SMEs, may encourage activities related to knowledge management, such as knowledge sharing, since those are time-consuming and require a certain level of trust (Durst and Wilhelm, 2011).

With a view to this background information about KM and SMEs, the following sections purport to determine whether or not the activities referred to above are in fact advantageous to SMEs.

\section{Methodology of literature review}

Our review was based on the principles of a systematic review as recommended by Jesson et al. (2011). We were interested in the current status of research into the advantages of KM in SMEs in order to determine likely fields for future research. We began by compiling a research plan containing the research questions we wanted to answer, the keywords, and a set of inclusion and exclusion criteria. The questions are to be found in the introduction.

To ensure pertinent answers to our research questions, we specified a priori inclusion and exclusion criteria. Our inclusion criteria were: empirical research papers, peer reviewed, English language, SME focus, focus on KM benefits/outcomes, and ProQuest/Web of Science database. We excluded papers dealing with regional clusters, grey literature such as reports and non-academic research, other languages than English, and other databases than ProQuest/Web of Science. With a view to the dearth of studies relating to KM benefits, we did not set a specific time limit. Additionally, we compiled an excel data sheet containing key aspects relevant to our research aim. In our case these were: name of author(s), year of publication, research aim/objectives, method, main findings, and name of the journal. After specifying all the appropriate issues, each of us accessed ProQuest/Web of Science and searched for materials, using the keywords set. We used the keywords knowledge benefits/outcome and SMEs which resulted in 409 hits in ProQuest and 80 hits in Web of Science. In order to ensure that our search included all papers from relevant journals we also explored the homepages of the highest ranked KM journals according to Serenko and Bontis (2009). These are the Journal of Knowledge Management, Journal of Intellectual Capital and Knowledge Management Research and Practice. In addition we searched three international ISI-journals in the field of SMEs International Small Business Journal, Journal of Small Business Management and Entrepreneurship Theory and Practice. This search resulted in additional 190 hits.

Subsequently, each of us scanned the articles' titles, abstracts and, if relevant, more parts, beginning with the conclusion section, to make sure that they actually fell within our scope of interest. Nine papers fulfilled the established criteria and thus constituted the foundation for our analysis.

In the next phase of our work we discussed the findings. This assisted us in forming a clearer picture of what we know about the advantages of KM in SMEs and what we should know. Finally, we wrote up our findings.

\section{Results}

\subsection{Studies involved}

The nine papers that formed the basis for our analysis are summarised in Table 1. The oldest publication is from 2005 and the most recent ones from the year 2011. Most of the papers were published in 2011, indicating a growing interest in the subject. Papers from 2012 have not been identified. The small number of papers clearly indicates serious lack of knowledge in this field of study.

Table 1. Overview of empirical papers involved in the literature review

\begin{tabular}{|c|c|c|c|c|c|c|}
\hline Author(s) & Year & Research aim & $\begin{array}{l}\text { Theoretical } \\
\text { perspective }\end{array}$ & Method & Main findings & Journal \\
\hline $\begin{array}{l}\text { Salojärvi, } \\
\text { Furu \& } \\
\text { Sveiby }\end{array}$ & 2005 & $\begin{array}{l}\text { To examine the } \\
\text { relationship } \\
\text { between } \\
\text { sustainable } \\
\text { sales growth } \\
\text { and KM } \\
\text { activities }\end{array}$ & $\begin{array}{l}\text { Literature } \\
\text { on KM and } \\
\text { SMEs, and } \\
\text { SME } \\
\text { growth }\end{array}$ & $\begin{array}{l}\text { Combination of } \\
\text { standardized } \\
\text { questionnaire } \\
\text { from } 108 \\
\text { Finnish SMEs } \\
\text { and semi- } \\
\text { structured }\end{array}$ & $\begin{array}{l}\text { Higher levels of KM maturity } \\
\text { were found to correlate } \\
\text { positively with long-term } \\
\text { sustainable growth of SMEs. }\end{array}$ & JKM \\
\hline
\end{tabular}




\begin{tabular}{|c|c|c|c|c|c|c|}
\hline Edvardsson & 2006 & $\begin{array}{l}\text { To expand our } \\
\text { knowledge on } \\
\text { KM in SME } \\
\text { (focusing on } \\
\text { Icelandic } \\
\text { SMEs) }\end{array}$ & \begin{tabular}{l}
\multicolumn{2}{l}{ Literature } \\
related to \\
$\mathrm{KM}$ in \\
SMEs
\end{tabular} & $\begin{array}{l}\text { interviews with } \\
\text { ten of the } 108 \\
\text { companies } \\
\text { Questionnaire } \\
\text { sent to the Chief } \\
\text { Executive of } \\
\text { Icelandic SMEs, } \\
\mathrm{n}=265\end{array}$ & $\begin{array}{l}\text { Icelandic firms rely on an } \\
\text { unsystematic manner of } \\
\text { sharing and utilising } \\
\text { knowledge, few have a KM } \\
\text { strategy and they mainly use } \\
\text { unsophisticated ICT } \\
\text { technologies. Those who had } \\
\text { KM reported many benefits, } \\
\text { such as improved decision } \\
\text { making, better customer } \\
\text { handling, improved staff } \\
\text { retention and increased } \\
\text { competitive advantage. }\end{array}$ & KMRP \\
\hline Edvardsson & 2009 & $\begin{array}{l}\text { To examine } \\
\text { whether the } \\
\text { popularity of } \\
\text { KM in SMEs } \\
\text { in Iceland has } \\
\text { decreased or } \\
\text { declined since } \\
2004\end{array}$ & $\begin{array}{l}\text { Literature } \\
\text { related to } \\
\mathrm{KM} \text { in } \\
\text { SMEs }\end{array}$ & $\begin{array}{l}\text { Questionnaire } \\
\text { sent to the Chief } \\
\text { Executive of } \\
\text { Icelandic SMEs } \\
(2007), \\
\text { repetition of a } \\
\text { previous survey } \\
(2004), n=224\end{array}$ & $\begin{array}{l}\text { KM is not losing ground } \\
\text { among SMEs in Iceland in } \\
\text { 2004-2007. Many more firms } \\
\text { have no KM strategy than in } \\
\text { 2004. Those who had KM } \\
\text { reported many benefits, such } \\
\text { as improved decision } \\
\text { making, better customer } \\
\text { handling, improved staff } \\
\text { retention and increased } \\
\text { competitive advantage. }\end{array}$ & KMRP \\
\hline Migdadi & 2009 & $\begin{array}{l}\text { To develop a } \\
\text { conceptual } \\
\text { research model } \\
\text { which } \\
\text { comprises both } \\
\text { CSFs and } \\
\text { outcomes and } \\
\text { empirically } \\
\text { assesses the } \\
\text { relationships } \\
\text { between CSFs } \\
\text { and } \\
\text { performance } \\
\text { outcomes in } \\
\text { SMEs }\end{array}$ & $\begin{array}{l}\text { Literature } \\
\text { related to } \\
\mathrm{KM} \text { CSFs } \\
\text { in } \mathrm{SMEs} \\
\text { and } \mathrm{KM} \\
\text { performanc } \\
\text { e outcomes }\end{array}$ & $\begin{array}{l}\text { Data were } \\
\text { collected from } \\
25 \text { SMEs in } \\
\text { Saudi Arabia; } \\
\text { multiple } \\
\text { regression } \\
\text { analyses }\end{array}$ & $\begin{array}{l}\text { Study underlined the positive } \\
\text { relationship between CSFS } \\
\text { and KM outcomes (i.e. } \\
\text { systematic } \\
\begin{array}{l}\text { activities, } \\
\text { development, } \\
\text { satisfaction, good expledge } \\
\text { relationships } \\
\text { organizational success) }\end{array}\end{array}$ & IMDS \\
\hline $\begin{array}{l}\text { Steenkamp } \\
\text { \& Kashyap }\end{array}$ & 2010 & $\begin{array}{l}\text { To provide } \\
\text { empirical } \\
\text { evidence of } \\
\text { SME managers' } \\
\text { perceptions } \\
\text { about the } \\
\text { importance and } \\
\text { contribution of } \\
\text { intangible } \\
\text { assets to their } \\
\text { business }\end{array}$ & $\begin{array}{l}\text { Literature } \\
\text { about the } \\
\text { importance } \\
\text { and } \\
\text { contribution } \\
\text { of } \\
\text { intangible } \\
\text { assets }\end{array}$ & $\begin{array}{l}\text { Postal } \\
\text { questionnaire } \\
\text { sent to New } \\
\text { Zealand SMEs }\end{array}$ & $\begin{array}{l}\text { Findings indicated that } \\
\text { intangibles are important and } \\
\text { are perceived as value drivers } \\
\text { of business success. } \\
\text { Customer satisfaction was } \\
\text { ranked as the most important, } \\
\text { followed by customer loyalty, } \\
\text { corporate reputation, and } \\
\text { product reputation. }\end{array}$ & $\mathrm{JIC}$ \\
\hline
\end{tabular}




\begin{tabular}{|c|c|c|c|c|c|c|c|}
\hline $\begin{array}{l}\text { Soon } \\
\text { Zainol }\end{array}$ & $\&$ & 2011 & $\begin{array}{l}\text { To examine the } \\
\text { importance of } \\
\text { the knowledge } \\
\text { creation } \\
\text { process, by } \\
\text { looking at } \\
\text { knowledge } \\
\text { management } \\
\text { enablers such } \\
\text { as learning and } \\
\text { T-shaped skills }\end{array}$ & $\begin{array}{l}\text { Literature } \\
\text { related to } \\
\mathrm{KM}, \\
\text { learning and } \\
\text { innovation }\end{array}$ & $\begin{array}{l}\text { Questionnaire, } \\
110 \quad \text { replies } \\
(10.2 \%), \\
\text { regression } \\
\text { analysis; } \\
\text { Malaysia }\end{array}$ & $\begin{array}{l}\text { Learning and T-shaped skills } \\
\text { are positively related to the } \\
\text { knowledge creation process, } \\
\text { enhancing organizational } \\
\text { creativity and performance. }\end{array}$ & ASS \\
\hline $\begin{array}{l}\text { Wei, } \\
\text { \& Chew }\end{array}$ & & 2011 & $\begin{array}{l}\text { To study the } \\
\text { the imple- } \\
\text { mentation of } \\
\text { KM processes } \\
\text { in Malaysian } \\
\text { SMEs }\end{array}$ & $\begin{array}{l}\text { General } \\
\text { KM } \\
\text { literature }\end{array}$ & $\begin{array}{l}\text { Questionnaire, } \\
70 \text { replies from } \\
\text { SMEs } \\
\text { owners/mana- } \\
\text { gers }(20 \%) \text {, } \\
\text { Malaysia }\end{array}$ & $\begin{array}{l}\text { Some of the highest benefits } \\
\text { of KM are related to } \\
\text { innovation, } \\
\begin{array}{l}\text { improved } \\
\text { decision-making processes, } \\
\text { competitive advantage, } \\
\text { efficiency and } \\
\text { product/service quality. }\end{array}\end{array}$ & KMRP \\
\hline Liao & & 2011 & $\begin{array}{l}\text { To study the } \\
\text { performance } \\
\text { effects of } \\
\text { interaction of } \\
\text { KM with HRM } \\
\text { control. }\end{array}$ & $\begin{array}{l}\text { Literature } \\
\text { on KM and } \\
\text { HRM } \\
\text { control }\end{array}$ & $\begin{array}{l}\text { Survey among } \\
\text { managers in } \\
\text { computer and } \\
\text { peripheral } \\
\text { equipment } \\
\text { manufacturing } \\
\text { industries in } \\
\text { Taiwan. } \\
\text { responses } \\
(29.6 \%)\end{array}$ & $\begin{array}{l}\text { The findings show that firms } \\
\text { emphasising personalization } \\
\text { strategy and HRM } \\
\text { behavioural control have a } \\
\text { better performance (growth } \\
\text { rate, market share, } \\
\text { profitability etc.). When } \\
\text { codification strategy is used } \\
\text { by firms, } \\
\text { the combination with output } \\
\text { based HRM will improve } \\
\text { their performance. No single } \\
\text { HRM system is related to } \\
\text { firms combining strategies. }\end{array}$ & IJM \\
\hline $\begin{array}{l}\text { Capó- } \\
\text { Vicedo, } \\
\text { Mula } \\
\text { Capó }\end{array}$ & $\&$ & 2011 & $\begin{array}{l}\text { To provide a } \\
\text { social network } \\
\text { model for } \\
\text { improving } \mathrm{KM} \\
\text { in multi-level } \\
\text { supply chains } \\
\text { formed } \\
\text { SMEs }\end{array}$ & $\begin{array}{l}\text { Literature } \\
\text { on KM and } \\
\text { social } \\
\text { networking }\end{array}$ & $\begin{array}{l}\text { Case studies } \\
\text { among } 10 \\
\text { construction } \\
\text { firms in Spain. }\end{array}$ & $\begin{array}{l}\text { The findings show how } \\
\text { establishing these } \\
\text { inter-organizational } \\
\text { relationships between } \\
\text { construction firms improves } \\
\text { confidence, communication } \\
\text { and team spirit. The result is } \\
\text { a higher degree of } \\
\text { innovation, fewer losses and } \\
\text { improvement in effienciency } \\
\text { and production. }\end{array}$ & SCM \\
\hline
\end{tabular}

\subsection{KM benefits in SMEs}

Table 2 shows the benefits reported in the papers reviewed. We grouped the benefits mentioned in the papers on the basis of the five dimensions proposed by Choy et al. (2006). It is evident that small businesses can substantially benefit from applying knowledge management initiatives. Almost all of the papers involved report of some kind of organizational success, such as growth in sales, fewer losses, increased productivity and process improvements. The 
papers also stress employee development (enhanced skills, learning, staff retention); improved customer satisfaction (customer loyalty, reputation, etc), innovation, creativity and knowledge creation, and improved external relationships with other firms. One study highlighted the significance of a strategic fit between KM practice and HRM policy with respect to organizational performance (Liao, 2011).

Table 2. KM benefits identified in the literature

\begin{tabular}{ll}
\hline KM benefits & Studies \\
Organizational success & Migladi (2009) \\
Sustainable growth & Salajärvi et al. (2005); Wei et al. (2011) \\
Sales growth & Salajärvi et al. (2005); Wei et al. (2011) \\
Increased profits & Edvardsson (2006, 2009) \\
Improved efficiency & Wei et al. (2011) \\
Flexibility & Wei et al. (2011) \\
Reduced costs & Edvardsson (2006, 2009); Wei et al. (2011) \\
Fewer losses & Capó-Vicedo et al. (2011). \\
Increased productivity & Edvardsson (2006, 2009) \\
Better decision making & Edvardsson (2006, 2009); Wei et al. (2011) \\
Faster response to key business processes & Edvardsson (2006, 2009) \\
Competitive advantage & Wei et al. (2011) \\
Market share & Liao (2011): Wei et al. (2011) \\
Employee development & Edvardsson (2006, 2009); Wei et al. (2011) \\
Staff retention & Migladi (2009) \\
Employee development & Soon and Zainol (2011); Wei et al. (2011) \\
Learning, learning curve & Edvardsson (2006, 2009) \\
Improved employee skills & Capó-Vicedo et al. (2011). \\
Team spirit & Migladi (2009); Steenkamp and Kashyap (2010) \\
Customer satisfaction & Edvardsson (2006, 2009) \\
Better customer handling & Steenkamp and Kashyap (2010) \\
Customer loyalty & Steenkamp and Kashyap (2010) \\
Corporate reputation & Steenkamp and Kashyap (2010) \\
Product reputation & Wei et al. (2011) \\
Product/Service quality & \\
Systematic knowledge activities & Edvardsson (2006, 2009); Wei et al. (2011) \\
New production development & Wei et al. (2011) \\
Innovation & Soon and Zainol (2011) \\
Knowledge creation & Soon and Zainol (2011 \\
Organizational creativity & Edvardsson (2006, 2009) \\
New ways of working & Migladi (2009); Capó-Vicedo et al. (2011). \\
Good external relationship & Capó-Vicedo et al. (2011). \\
Communication & \\
Strategy & Liao (2011) \\
Fit between KM and HRM strategy & \\
&
\end{tabular}

\subsection{Where were the studies conducted?}

The studies reviewed had been conducted in Europe (i.e. Finland, Iceland and Spain); one in Saudi-Arabia, one in New Zealand, and two in Asia (i.e. Malaysia and Taiwan).

\subsection{Methods used}

Eight out of nine studies were based on survey approaches where statistical analysis involving a variety of sophistication had been applied. One project was founded on a case study (Capó-Vicedo et al., 2011). Other research methods were not applied.

\section{Discussion and conclusion}

The aim of this paper was to identify the body of knowledge regarding KM benefits in SMEs. It is important to improve our understanding of what we know about this topic to better position the topic of KM and its actual relevance. 
Our systematic literature search resulted in nine empirical studies. This suggests that to date KM research is rather imbalanced. Even though a high volume of papers has been produced on KM and its apparent relevance to organizations, current KM research has failed to demonstrate clear benefits related to KM activities. More contributions regarding KM benefits are, however, important since otherwise organizations, and specifically smaller firms, will allocate their resources to other business areas promising a better return on investment. This, as well as our findings, is the reason why we call for more intense research.

As referred to above, our literature review comprised nine papers. The reviewed studies highlight the benefits of knowledge management in the areas of employee development, innovation, customer satisfaction and organizational success. From these findings we put forward the following propositions:

Proposition 1: SMEs adopting KM systems and techniques will benefit from organizational success, such as sales growth, cost reduction and increased productivity.

Proposition 2: Assuming that there is a fit between KM and HRM strategy they both in combination will contribute to a better management of SMEs and consequently organizational success in this sector.

Proposition 3: The application of KM systems and techniques in SMEs contributes positively to employee development and retention.

Proposition 4: KM systems and techniques positively influence customer satisfaction in SMEs.

Proposition 5: KM systems and techniques help SMEs to better address the issues of knowledge creation and innovation.

Proposition 6: KM systems and techniques help SMEs to expand their social capital with external stakeholders.

With regard to the methods used, we observed a bias towards surveys. Survey approaches, however, are less suitable for the collection of detailed information (Saunders and Lewis, 2012). Even though the studies reviewed have highlighted different KM benefits, they are phrased in general terms. For example, what are "new ways of working" as found by Edvardsson $(2006,2009)$ or how was "customer satisfaction" determined as reported by Migdadi (2009) and Steenkamp and Kashyap (2010)? The causal relationship between KM programmes and innovation, customer relationships and competitive advantage is still missing in the literature (Edvardsson and Oskarsson, 2011). Additionally, as activities related to KM are characterised by a long-term process and influenced by different interrelated determinants, the actual benefits of KM will also be similarly affected. Consequently, to understand this crucial link between KM initiatives and KM benefits, respectively, future research would be aided by longitudinal research designs as they would bring us closer to this link. Having this in mind and building upon Migdadi's approach (2009) future research would also gain from a more holistic approach towards studying KM in general and KM benefits in particular. Only this would allow us to understand KM in its entire breadth.

As regards location, research in this area seems to be primarily driven by certain researchers' personal interests. No region or country has come to the fore to date. Given the relevance of SMEs on an international level (Greene and Mole, 2006), research in the area would definitely benefit from contributions from more parts of the world. In addition, the literature review clearly shows that the studies had a single-region or single-country emphasis. Consequently, we argue that there is a necessity to start comparative research activities which would give us an opportunity to discuss and understand how culture, religion and gender relations affect KM in SMEs, especially trust in knowledge sharing, as well as the quality of relationships between SMEs and customers and suppliers, or other knowledge providers. The formation of research networks to join forces on the matter of KM benefits may also be a way of disseminating the outcomes of the studies and their findings and of attracting more interest from other researchers.

$\mathrm{KM}$ research as a field is still characterised by a high degree of heterogeneity when it comes to the applications of terms and constructs. This situation definitely hampers the development of the field in general, and the topic of KM benefits in particular, as studies are difficult to compare. Therefore, more intense research on conceptual issues is needed as well.

We are aware that the present study is not without limitations. This study may not have achieved complete coverage of all empirical articles in the field of KM benefits in SMEs. Yet, it seems reasonable to assume that the review process covered a large share of studies available.

\section{References}

Andreeva, T. \& Kianto, A. (2012). Does knowledge management really matter? Linking knowledge management practices, competitiveness and economic performance. Journal of Knowledge Management, 16 (4), 617-636. 
http://dx.doi.org/10.1108/13673271211246185

Beijerse, R. P. (2000). Knowledge management in small and medium-sized companies: knowledge management for

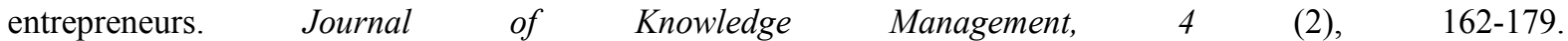
http://dx.doi.org/10.1108/13673270010372297

Bozbura, F. T. (2007). Knowledge management practices in Turkish SMEs. Journal of Enterprise Information Management, 20 (2), 209-221. http://dx.doi.org/10.1108/17410390710725788

Capó-Vicedo, J., Mula, J., Capó, J. (2011). A social network-based organizational model for improving knowledge management in supply chains. Supply Chain Management: An International Journal, 16 (4), 284-293. http://dx.doi.org/10.1108/13598541111139099

Chong, C. W. \& Chong, S. C. (2009). Knowledge management process effectiveness: measurement of preliminary knowledge management implementation. Knowledge Management Research \& Practice, 7 (2), 142-151. http://dx.doi.org/10.1057/kmrp.2009.5

Choy, C. S., Yew, W. K. \& Lin, B. (2006). Criteria for measuring KM performance outcomes in organizations. Industrial Management \& Data Systems, 106 (7), 917- 936. http://dx.doi.org/10.1108/02635570610688850

Corso, M., Martini, A., Paolucci, E. \& Pellegrini, L. (2003). Knowledge management configurations in Italian small-to-medium enterprises. Integrated Manufacturing Systems, $14 \quad$ (1), 46-57. http://dx.doi.org/10.1108/09576060310453344

Culkin, N. \& Smith, D. (2000). An emotional business: a guide to understanding the motivations of small business decision takers. Qualitative Market Research: An International Journal, 3 (3), 145-157. http://dx.doi.org/10.1108/13522750010333898

Daft, R. F. (2007). Understanding the theory and design of organizations. Mason: Thomson South-Western.

Davenport, T. H. \& Prusak, L. (1998). Working Knowledge. How Organizations Manage What They Know. Boston, Ma.: Harvard Business School Press.

Durst, S. \& Wilhelm, S. (2011). Knowledge management in practice: insights into a medium-sized enterprise's exposure to knowledge loss. Prometheus, 29 (1), 1-16. http://dx.doi.org/10.1080/08109028.2011.565693

Durst, S., \& Edvardsson, I. R. (2012). Knowledge Management in SMEs: A Literature Review. Journal of Knowledge Management, 16, (6), 879-903. http://dx.doi.org/10.1108/13673271211276173

Edler, J. (2003). How German companies employ knowledge management. An OECD survey on usage, motivations and effects. In K. Mertins, P. Heisig and J. Vorbeck (Eds.), Knowledge Management: Concepts and Best Practices (pp. 207-221). Berlin: Springer, 207-221.

Edvardsson, I. R. (2006). Knowledge Management and SMEs: The case of Icelandic firms. Knowledge Management Research \& Practice, 4 (4), 275-282. http://dx.doi.org/10.1057/palgrave.kmrp.8500111

Edvardsson, I. R. (2008). HRM and knowledge management. Employee Relations, 30 (5), 553-561. http://dx.doi.org/10.1108/01425450810888303

Edvardsson, I. R. (2009). Is knowledge management losing ground? Developments among Icelandic SMEs. Knowledge Management Research \& Practice, 7 (1), 91-99. http://dx.doi.org/10.1057/kmrp.2008.30

Edvardsson, I. R. \& Oskarsson, G.. K. (2011). Knowledge management, and value creation in service firms. Measuring Business Excellence, 15, 4, 7-15. http://dx.doi.org/ 10.1108/13683041111184062

Greene, F. \& Mole, K. (2006). Defining and measuring the small business. In S. Carter and D. Jones-Evans, D. (Eds.), Enterprise and Small Business, 2nd ed. (pp. 7-29). Harlow: Pearson.

Hutchinson, V. \& Quintas, P. (2008). Do SMEs do Knowledge Management? Or simply manage what they know?" International Small Business Journal, 26 (2), 131-154. http://dx.doi.org/10.1177/0266242607086571

Jashapara, A. (2011). Knowledge management: An integrated approach. Harlow: Prentice Hall.

Jesson, J. K., Matheson, L. \& Lacey, F. M. (2011). Doing your literature review: Traditional and systematic techniques. Sage: Los Angeles.

Liao, Y.-S. (2011). The effect of human resource management control systems on the relationship between knowledge management strategy and firm performance. International Journal of Manpower, 32 (5/6), 494-511. http://dx.doi.org/10.1108/01437721111158170 
Lim, K. K. \& Ahmed, P. K. (2000). Enabling Knowledge Management: A Measurement Perspective. [Online] Available: http://ieeexplore.ieee.org/iel5/7328/19806/00916781.pdf.

KPMG Consulting (2000). Knowledge Management Research Report 2000. Annapolis/London.

Kluge, J., Wolfram, S. \& Licht, T. (2001). Knowledge Unplugged. The McKinsey \& Company global survey on knowledge management. Houndsmill: Palgrave. http://dx.doi.org/10.1057/9780333977057

Markus, L. M. (2001). Toward a Theory of Knowledge Reuse: Types of Knowledge Reuse Situations and Factors in Reuse Success. Journal of Management Information Systems, 18, (1), 57-93.

Matlay, H. (2000). Organisational learning in small learning organisations: An empirical overview. Education + Training, 42 (4/5), 202-211. http://dx.doi.org/10.1108/00400910010373642

McAdam, R. \& Reid, R. (2001). SME and large organisation perceptions of knowledge management: comparisons and contrasts. Journal of Knowledge Management, 5 (3), 231-241. http://dx.doi.org/10.1108/13673270110400870

Nonaka, I. \& Takeuchi, H. (1995). The Knowledge-Creating Company. Oxford: Oxford University Press.

Migdadi, M. (2009). Knowledge management enablers and outcomes in the small-and-medium sized enterprises. Industrial Management + Data Systems, 109 (6), 840-858. http://dx.doi.org/10.1108/02635570910968072

O’Dell, C., Hubert, C., Lopez, K., Odem, P. \& Raybourn, C. (2003). Successful KM implementations: a study of best-practice organizations. In C. W. Holsapple, (Ed), Handbook on Knowledge Management, Vol. 2 (pp. 411-441). Berlin: Springer, 411-441.

O'Dell, C. \& Hubert, C. (2011). The New Edge in Knowledge: How knowledge management is changing the way we do business. Hoboken, New Jersey: John Wiley and Sons, Inc.

Oltra, V. (2005). Knowledge management effectiveness factors: the role of HRM. Journal of Knowledge Management, 9 (4), 70-86. http://dx.doi.org/10.1108/13673270510610341

Salojärvi, S., Furu, P. \& Sveiby, K.-E. (2005). Knowledge management and growth in Finnish SMEs. Journal of Knowledge Management, 9 (2), 103-122. http://dx.doi.org/10.1108/13673270510590254

Saunders, M. \& Lewis, P. (2012). Doing Research in Business \& Management. An Essential Guide to Planning your Project. Harlow: Pearson.

Serenko, A. \& Bontis, N. (2009). Global ranking of knowledge management and intellectual capital academic journals, Journal of Knowledge Management, 13 (1), 4-15. http://dx.doi.org/10.1108/13673270910931125

Steenkamp, N. \& Kashyap, V. (2010). Importance and contribution of intangible assets: SME managers' perceptions. Journal of Intellectual Capital, 11 (3), 368-390. http://dx.doi.org/10.1108/14691931011064590

Soon, T. T. \& Zainol, F. A. (2011). Knowledge Management Enablers, Process and Organizational Performance: Evidence from Malaysian Enterprises. Asian Social Science, 7 (8), 186-202. http://dx.doi.org/10.5539/ass.v7n8p186

Tsui, E. (2003). Tracking the Role and Evolution of Commercial Knowledge Management Software. In C. W. Holsapple (Ed.). Handbook on Knowledge Management, Vol. 2 (pp. 5-27). Berlin: Springer, 5-27.

Wei, C. C., Choy, C. S. \& Chew, G. G. (2011). The KM processes in Malaysian SMEs: an empirical validation. Knowledge Management Research and Practice, 9 (2), 185-196. http://dx.doi.org/10.1057/kmrp.2011.8

Wiig, K. M. (1997). Knowledge Management: An Introduction and Perspective. Journal of Knowledge Management, 1 (1), 6-14. http://dx.doi.org/10.1108/13673279710800682

Wong, K. Y. \& Aspinwall, E. (2004). Characterizing knowledge management in the small business environment. Journal of Knowledge Management, 8 (3), 44-61. http://dx.doi.org/10.1108/13673270410541033 